\title{
ACADEMIC DUTY AND COMMUNAL OBLIGATION REVISITED ${ }^{1}$
}

In 1992 Oxford University Press, published my book Modern British Jewry. The volume may be regarded in some sense as a sequel to another book, published by Oxford a halfcentury ago. I refer, of course, to the late Dr. Cecil Roth's History of the Jews in England, which first appeared in 1941 and which went into three editions.

It has become fashionable now to dismiss this work. Professor David Katz has pointed out that Roth's writings in the field of Anglo-Jewish history were 'full of mistakes, undocumented assertions, and numerous gaps. ${ }^{2}$ So they were. It is the fate of all pioneers to have their mistakes uncovered by those who come after them, and to have their theories cast aside. But to say these things is to miss the point. Yes, Roth's History was sanitized, apologetic, complacent; it stopped with Emancipation, in 1858, in part because Roth wished, for propaganda purposes, to end on a note of triumph; he felt uncomfortable dealing with the era of the great immigration of Jews to Britain in the 1880s and 1890s, and with the anti-Jewish prejudice in Britain which this immigration triggered. As Professor Katz himself rightly observes, 'Roth was a pioneer who worked very largely during the blackest era of Jewish history, when it seemed that the very last thing the Jews needed was avoidable criticism from within, supplying genuine arguments to even more genuine anti-Semites.' 3

1941 was not a good year for the Jews. Roth, like so many other British Jews, did not know how to cope with the reality of the Holocaust. He adopted a then conventional explanation, that the sufferings of the Jews were a test. He was right to contrast these sufferings, ordered by Nazi Germany but carried out with the help of many other European nations, with the relative tranquillity of the Jews in Britain; here was a debt that

\footnotetext{
1 This is a revised and updated version of a paper first delivered and published under the auspices of the Centre for Jewish Studies, University of London, 1994.

${ }^{2}$ D.S. Katz, 'The Marginalization of Early Modern Anglo-Jewish History', Immigrants \& Minorities, 10(1991), 61.

${ }^{3}$ Ibid.
} 
had to be acknowledged and paid. Roth saw it as a solemn duty to pay it. But even in so doing, he wrought a sea-change in the researching and writing of British- Jewish history.

History is the collective memory of a people and in large measure shapes their view of the present and of the future. That is why I devote some space, in my book, to the way in which Jews in Britain have approached and interpreted their past.

The first history of Anglo-Jewry to be written by an Anglo-Jewish writer appeared in 1847, a slim pamphlet, published in Chambers Miscellany, the work of a woman of Marrano descent, Grace Aguilar (1816-47). 'Jews', she declared, 'are still considered aliens and foreigners ... little known and less understood. Yet they are, in fact, Jews only in their religion - Englishmen in everything else.' 'A Jewish murderer, adulterer, burglar, or even petty thief, she added coolly, 'is actually unknown'.

We may smile at the sweeping superficiality and patent dishonesty of such statements. There were plenty of Jewish criminals in Britain in the 1830s and 1840s, and it is difficult to believe that Aguilar did not know about them. Criminality among the Jewish poor obsessed the communal grandees at this time: the dramatic escape from police custody in 1827 of Ikey Solomons, on whom Dickens is thought by some to have modelled Fagin; the trial of Sol Litsenberg, indicted at Marlborough Street Police Court in 1830 for running a gang of 20 juvenile thieves in the vicinity of Leicester Square; the scandals which arose from cases of Jewish-run houses of easy virtue, condemned by Ashkenazi Chief Rabbi Hirschell in 1836. The Jewish 'fence,' dealing in stolen property, was a feature of Petticoat Lane market throughout the mid-Victorian period, and its eradication was felt by many of the lay leaders of British Jewry to be an essential pre-requisite of full political emancipation. Considerations of image obsessed the leadership then, just as considerations of image obsess the leadership now.

Historians were expected to play their part in maintaining the image intact. In 1993 the Jewish Historical Society celebrated its centenary. It is worth recalling that the notion of establishing a society devoted to Anglo-Jewish history was viewed with not a little 
misgiving, and that those who established it and who supported its establishment were at pains to justify its existence in terms of the good account it would give, to the Gentiles, of the Jewish people.

In his inaugural address to the Society the journalist Lucien Wolf, its first president, gave this assurance. Wolf wrote extensively on Anglo-Jewish historical themes, concentrating especially upon the period of the Resettlement, and writing in the style of an earlier generation of Anglo-Jewish historians (principally Myer Davis and James Piciotto), whose work in the 1870s forms the bridge between Grace Aguilar and Lucien Wolf himself. Cecil Roth learnt his craft from Lucien Wolf, to whom he referred, in adulatory terms, in his last address to the Jewish Historical Society, in 1968.

Roth felt the weight of this responsibility very heavily and very personally. But he gave to the researching and writing of Jewish history a scholastic basis which it had not had hitherto. As the late Professor Lloyd Gartner observed, 'Jewish history as a profession virtually did not exist during the 1920s', when Roth made that fateful decision to turn from the history of Renaissance Italy to that of Italian Jewry and then of Anglo-Jewry. ${ }^{4}$ The researching and writing of Anglo-Jewish history had hitherto been the preserve of non- scholastic apologists like Grace Aguilar and Lady Magnus, gifted amateurs like Davis and Wolf, and ministers of religion who, as Roth himself observed, regarded Jewish history 'almost as a branch of theology.' ${ }^{5}$ Roth, single-handedly, transformed Anglo-Jewish historiography into a scholarly activity worthy of pursuit at the highest university levels.

British Jewry recognised his achievements, and marked them. The Readership in PostBiblical Jewish Studies which he held at Oxford from 1939 to 1964 was created for him through a communal benefaction. But he had to sing - so to speak - for his supper. Approached by the then President of the Federation of Synagogues (the crook Morry Davis) to write the Federation's jubilee history (1937), Roth was obliged to pen what can

\footnotetext{
4 L.P. Gartner, 'Cecil Roth, Historian of Anglo-Jewry', in D. Noy \& I. Ben-Ami (eds), Studies in the Cultural Life of the Jews in England (Jerusalem, 1971), 71.

5 Quoted ibid., 83.
} 
only be described as a pamphlet, so superficial and wanting in scholastic rigour that he was too ashamed to include it in a list of his own publications. It is, I think, quite well known that the celebratory centenary history of the Jewish Chronicle, which appeared in 1949, was written by Roth; but he would not permit his name to appear in the title-page.

I was a student of Cecil Roth, and I remain an admirer. But I am in no sense an imitator, less still a disciple. Disciples and imitators there certainly were. Foremost amongst these were Albert Hyamson (1875-1954) and Vivan Lipman (1921-90). Hyamson's history of The Sephardim in England, which appeared in 1951, was written very much in the Roth mould: apologetic, highly selective, uncritical. The volume was meant to cover the two centuries 1492 to 1951; in fact precisely twenty pages, in a work of over 460, were devoted to the 20th century, and much was left unsaid into the bargain. The controversial reign of Moses Gaster as Haham - that is, supreme rabbinical authority of the Spanish \& Portuguese Jews' Congregation of London- from 1887 to 1918 - was totally unexplored; nothing was said, that is, about the man who was Theodor Herzl's staunchest and earliest ally in Britain. Hyamson's excuse for all these omissions - 'The historian ought never to deal or attempt to deal with events of which he has a personal knowledge' - strikes me as lame indeed. But it was an excuse which Roth himself had proffered more than once to explain his own reluctance to deal with 20th century problems.

The late Vivian Lipman was a pupil of Roth, and a disciple in every sense of the word. As is well known, Lipman was a distinguished civil servant who rose to become Director of Ancient Monuments \& Historic Buildings at the Department of the Environment. He was an expert on medieval Anglo-Jewry - in some respects more of an expert than his teacher. But he was also more establishment-minded than his teacher, willing to curry favour with the communal grandees even if this meant being economical with the truth. When the then Jewish Board of Guardians, founded in 1859, decided to commission a centenary history, Vivian was not their first choice. They turned initially to a young Anglo-Jewish academic, an objective scholar in every sense of the word; this young man produced a chapter for the consideration of the grandees. They were horrified, for he had told the truth, the whole truth and nothing but the truth. The commission was naturally taken from him and given to Vivian Lipman instead. And the work which Vivian 
published, in 1959, is distinguished chiefly by its meticulous attention to detail, its highly descriptive approach, and its signal failure to explore, let alone explain, the abominable treatment, by the Jewish Board of Guardians, of Jewish refugees to Britain in the 1880s and 1890s.

Lipman's last book, his History of the Jews in Britain since 1858, was published posthumously a few months after his death. The bulk of the work was devoted to the period 1858 to 1939; precisely fifteen pages address the post-1945 period. The treatment throughout is descriptive, uncritical, highly selective and outrageously partial. Let me give a few examples.

When Russian persecution and economic hardship drove millions of Jews westwards in the 1880s and 1890s, the communal leadership did its best to prevent any but the most affluent of them from ever settling permanently in Britain. To this policy Lipman accorded just three inadequate sentences. In the 1930s a not entirely dissimilar policy was invoked to hinder the entry into Britain of refugees from Nazism. Vivian hinted darkly at this, but on the whole peddled the now discredited apologia of Norman Bentwich (They Found Refuge, 1956), whose defence of Otto Schiff, the man whom the Home Office trusted to select the 'right' type of German Jew to be permitted to enter Britain, has crumbled as archival material (of which Lipman was, I know, well aware) has become available for public inspection. Nor, except in terms of unashamed bias and lack of professionalism, is it possible to explain the complete absence, in Lipman's book, of any allusion to the stratagems devised by the leadership of the United Synagogue in the interwar period, to prevent Zionism becoming official United-Synagogue policy. It is, incidentally, worth remarking that the official historian of the United Synagogue, Professor Aubrey Newman, was himself strangely silent on this subject.

It would be comforting to think that we have heard the last of the 'Whig' historians of Anglo-Jewry, whose writings have been characterised as apologetic, sanitized, triumphant, uncritical, even 'cosy. ${ }^{6}$ I fear not, for I have recently [July 2016] been asked

${ }^{6}$ T.M. Endelman, 'English Jewish History', Modem Judaism, 11(1991), 92. 
to referee for a commercial publishing house a manuscript in which all these hallmarks appear in ample measure, as if the revolution of the past 40 years in Anglo-Jewish historiography had not taken place. ${ }^{7}$

I am proud to think that I played a part in that revolution. But I was not its prime mover. It cannot be without significance that the scholar who broke the mould of what had passed for Anglo-Jewish historiography hitherto, the late Professor Lloyd Gartner, was an American, a pupil of the great Salo Baron. Gartner's monograph The Jewish Immigrant in England first appeared in 1960. Gartner's view of the immigrants in the period 1870 to 1914 was that, at bottom, they had much less in common with the non-Jewish manual working classes amongst whom they dwelt than with the Jewish bourgeoisie to whose status and lifestyle they aspired. It is a view that has come under serious challenge, notably from Dr. Joseph Buckman in relation to Leeds Jewry and from Professor David Feldman and the later Professor William Fishman, whose use of Yiddish sources has set new standards for the study of the Anglo-Jewish proletariat.

My view is that both sides of the argument are right. In the short term, the immigrants had to confront life as they found it. This meant that they had to meet and make friends with the British proletariat, of which, perforce, they became a part. But we must remember that many of the Jewish immigrants who came to this country in states of penury had, in fact, been members of a petty bourgeoisie in Russia, Poland, Galicia and Romania. Their undoubted motivation for self-improvement derived in part from their ambition to recapture in Britain the status they had lost in Eastern Europe. The average British trade- unionist saw his or her life as beginning and ending in a working-class milieu; this was not a vision shared by Anglo-Jewish trade-unionists.

The major impact of the immigrants is to be found in the challenge they mounted to the rule of the so-called Cousinhood, that small group of interrelated monied families which

\footnotetext{
7 I recommended the manuscript's rejection. The publisher ignored my advice!
} 
affected to rule Anglo-Jewry in the age of emancipation. It has become fashionable to contrast the process of emancipation in Britain with that on the European mainland, where Jewish communities often had to undergo a formal renunciation of their separate ethnic and often internally self-governing status; as individuals Jews were offered absolute equality before the law, that is, but only on condition that communal rights were severely delimited. On the face of it, no such demand was ever made of the Jews in Britain.

In fact, we would be very wrong to conclude from the absence of a formal emancipation 'contract' that no concessions were extracted from British Jewry in return for the grant of civic rights. Emancipation, which Cecil Roth saw as the triumphant culmination of the Jewish existence in Britain, was bought at a very considerable cost, no more so than in the religious sphere.

For example, it was no coincidence that Reform Jews were to be found at the very forefront of the emancipation struggle, actually arguing, in a petition to Sir Robert Peel, the Prime Minister, in 1845 that emancipation should be granted as a reward, so to speak, for reform of the synagogue service to make it somewhat less Jewish and more English in form. Another example is provided by the status, in English law, of a rabbinically sanctioned divorce. When the Matrimonial Causes Act was passed in 1857, it was assumed that the hitherto undisputed freedom of the Jews to dissolve marriages contracted under rabbinical auspices would continue. But then another argument was heard: if the Jews wanted equality before the law, so be it - in every sphere. So the supremacy of the civil divorce court over the Beth Din (the Jewish ecclesiastical court) was established. How much less intractable would have been the present difficulties over Jewish divorce had this form of 'equality' not been imposed!

The generation of the emancipation wished for nothing better than to be accepted by the host society as Britons of the Jewish persuasion. The immigrants mounted a sustained challenge to this assimilatory view, by insisting upon the preservation of their separate 
ethnic identity and (worse still!) by parading it for all to see. For some, this ethnic separatism took a religious form - the establishment of the Federation of Synagogues in 1887 and of the Union of Orthodox Hebrew Congregations in 1926; for others it took a political form - the formation of Jewish trade unions and of a uniquely Jewish species of socialism and Labourism; for still others it took a cultural form - the maintenance of a rich Yiddish culture, theatre and newspaper press; and for others it took a geopolitical form - the assertion of provincial autonomy and rebellion against the rule of the London grandees.

All these discontents were exploited by the Zionists, who until the 1930s were really a very small band operating if not on the periphery of the Anglo-Jewish world then certainly at a remarkable distance from its centre. Our view of the Zionist dimension in Anglo-Jewish history has been transformed through the researches of Professor Stuart Cohen of Bar Ilan University and the late Professor David Cesarani of Royal Holloway University of London. It is, I fear, still but little understood now how very fashionable anti-Zionism was within British Jewry before 1939. The Zionist view was that the emancipation of the Jews in Europe had failed and was destined to fail because, at the end of the day, the Jews were simply not capable of assimilation within European societies. This was precisely the view of the Nazis. The established Jewish communities in Britain, obsessively anxious to maintain the image of British Jewry totally at one with its British environment, opposed both Zionism and Nazism for the same reason. So we encounter and enter upon one of the blackest phases of British-Jewish history, the reaction of British Jews to fascism at home and to Nazism abroad.

As to the former, in respect of which our knowledge has been immeasurably transformed by Professor Colin Holmes, the world's leading authority on anti-Jewish prejudice in Britain, by his pupil Professor Tony Kushner, and by my pupil Dr Thomas Linehan (now of Brunel University), it is clear now that the community, certainly as represented by the Board of Deputies of British Jews, was concerned less about protecting Jews from Gentiles than about protecting Gentiles from Jews. That is, the Board, in its communal defence policy, accepted and acted upon the view that Jews, by their behaviour, fostered and fomented antisemitism. 
Here I must pay tribute to the work of Dr. Louise London, whose London University doctoral thesis I was privileged to examine, and also to the work of my own postgraduate student, Mrs. Paula Hill. I do believe that in the immediate post-war period, and aided particularly by the euphoria generated by the re-establishment of the Jewish State so soon after the catastrophe of the Holocaust, there developed within British Jewry a collective amnesia (the guilt of those who survived, perhaps) about the precise nature of its own reaction to news of the Final Solution and to the plight of its Jewish victims. All I wish to say here is that I trust I have not disappointed those many Jewish fugitives from Nazism who hoped they would find a welcome from their British co-religionists, whose hopes were brutally dashed, and who have waited for over half a century for the truth to be told.

I have stressed that the preservation of image has been the uttermost priority of the Anglo-Jewish leadership through the ages. In Modern British Jewry, and its sequel British Jewry Since Emancipation (published by the University of Buckingham Press in 2014) I attempt to show how very divided the Jewish communities of Britain have become since the disappearance of the self- discipline imposed by the Holocaust years. The last Chief Rabbi who could truly claim to speak as the religious head of the Jews in Britain was Dr. Hertz, who held the office from 1913 to 1946. Hertz had problems coping with the left, so to speak, the Reform and Liberal movements, and from the right, the Union of Orthodox Hebrew Congregations and the Gateshead community. But in the shadow of the Nazi menace the various factions tacitly agreed to sink their differences. Under his successor, Israel Brodie, the fabric of religious unity so carefully constructed by the Adlers, father and son, during the 19th century began to fall apart, and during the tenure of office of his successor, Lord Jakobovits, the fabric was rent asunder. As I say in British Jewry Since Emancipation, Jakobovits bequeathed to Rabbi Dr. Jonathan Sacks 'an office less recognised throughout Jewish Britain than at any time since the Emancipation.'

Even before. Sacks' election, the suzerainty of the Chief Rabbinate had been publicly 
repudiated by the Federation of Synagogues, the Union of Liberal \& Progressive. Synagogues and the Assembly of Conservative Synagogues; subsequently it was repudiated also by the Reform Synagogues of Great Britain; it had never been recognised by the Union of Orthodox Hebrew Congregations or by the Spanish \& Portuguese Jews. Professor Barry Kosmin, then Director of the Research Unit of the Board of Deputies, calculated that in 1982 that the communities and congregations which acknowledged the authority of Jakobovits amounted to only $62 \%$ of synagogue members in the UK as a whole, and to only $53 \%$ in London; the proportions over whom Dr. Sacks could claim authority were certainly smaller, and diminished still further - to barely $50 \%$ - in the early years of the new millennium.

In my books I try to explain how and why this has happened, but I also emphasise that it is a development parallel to and not unconnected with a similar loss of prestige, status and, ultimately, authority, suffered by the Board of Deputies of British Jews. In times gone by, the wealthy within British Jewry played their part and took their place in the circles of the Board. That past is dead. There is now a more or less wholesale divorce between those who claim to speak as the representatives of British Jewry and those who control its purse strings, some of whom have defected to the upstart Jewish Leadership Council.

The Board is also a victim of the religious polarisation of Anglo-Jewry: it cannot claim to speak on behalf of the secular Jews, nor on behalf of the sectarian orthodox, represented by and through the Union, which walked out of the Board in 1971 and which has shown no sign of wanting to return. The Board has tried to paper over these fissures, but in so doing has been driven to ever more desperate remedies. The truth was - and is - bound to get out in the end. During the very bitter controversy between the Board and the Chief Rabbinate on the one hand, and a loose alliance of orthodox synagogal groupings, led by the Spanish \& Portuguese Jews, the Union and the Federation on the other, over the protection of shechita (the Jewish humane method of slaughter of food animals) in the late 1980s, the claim of the Board to 'represent' British Jewry was effectively quashed. It is now nothing more than a gigantic bluff. 
In some respects it is true that the publication of Professor Gartner's Jewish Immigrant in England proved to be a false dawn. ${ }^{8}$ Why was this? In the first place we must remember that this work came from the pen of an American scholar, thoroughly at home with the Hebrew and Yiddish sources as well as the English, and free from the subtle inhibitions and somewhat less subtle communal constraints that obtained in the United Kingdom. In the second, whereas the American university world was glad to offer homes to young scholars who had served their academic apprenticeships within the world of Jewish history (and, more generally, of Jewish studies), no such opportunities existed in the UK. Outside of the universities of Oxford, Cambridge and London Jewish history was hardly taught; where it was taught, it was likely to be only within departments of theology, classics and ancient history.

Happily, this is no longer the case. Modern Anglo-Jewish history has benefited from the increasing interest in 'ethnic' studies, and in the experience and impact of immigrant minorities in British - and more generally in European - urban communities. British Jewry itself has matured: it is no longer reluctant to confront its recent past. Scarcely less important has been the willingness of communal philanthropists to fund university posts in and university-level research into this recent past.

The history of the Jews has been recognised as a subject in its own right within the scope of the quinquennial government-mandated Research Assessment Exercises involving the taxpayer-funded higher-education sector in the UK. In the early 1990s the University of London approved the history of the Jews in Britain as a discrete optional subject within its Bachelor's programme in modern history. Today there is scarcely a university in the UK where it is not possible to study modern Anglo-Jewish history in some form. Of particular note - but this list is far from exhaustive - are the Oxford Centre for Hebrew \& Jewish Studies, the Department for Hebrew \& Jewish Studies at University College London, the Centres for Jewish Studies at the University of Manchester and at the School of Oriental \& African Studies, and the Parkes Institute and Library at the University of Southampton, which houses the largest single collection of private archives bearing upon the history of the Jews in the UK. We might also note that a number of leading

${ }^{8}$ Geoffrey Alderman, 'The Canon,' Times Higher Education, 28 May 2009, 49. 
communal bodies have been persuaded to transfer their own archives (often inadequately housed hitherto) to the expert care of London Metropolitan Archives.

At the same time the academic study of Anglo-Jewish history has flourished in the United States of America, where some of its most brilliant contemporary expositors - I am thinking particularly of Professor Todd Endelman - are to be found. It is a particular tribute to these expositors that they, and their students, have managed to maintain and expand this scholarship in spite of the ocean that separates them from their subjectmatter.

In my writings I have built on foundations dug by others, but the building is mine, and I am responsible for its faults and imperfections. With whatever shortcomings its detractors may find fault, it is my child, and I shall extend to it the full measure of my protection. Some of you may wonder why I speak in these terms. I choose my words carefully and I voice them with good reason. Any professional historian working in the field of BritishJewish history knows that he or she walks in a minefield, and that the assertion of too independent a judgment can bring down communal wrath in full measure.

I well recall how in the spring of 1989 my satisfaction in accepting an invitation from the Jewish Historical Society of England to deliver a paper to it was rudely interrupted when the then Programme Committee of the Society expressed its displeasure on learning that I proposed to talk on the career of Morry Davis, the aforementioned crook, one of the most important figures in Labour politics and political corruption in Stepney between the two World Wars. Their objection appears to have been not that I would say things about Davis that were untrue, or could not be supported by the evidence, but that what I would say would be only too true. I stood my ground, the Programme Committee backed off, and the paper was delivered - and printed.

In the Inaugural Lecture which I was privileged to give following my elevation to a Personal Chair at Royal Holloway College in 1989 I drew attention to this incident, but omitted to cite another, far graver, which had occurred but a few months previously. I had 
wished to examine a particular archive of the Board of Deputies. ${ }^{9}$ Because of its antisemitic nature I well understood the sensitivity of the Board on this matter, which I had raised, as a Deputy, on the floor of the Board. When, therefore, in October 1986, the then President of the Board, Dr. Lionel Kopelowitz, wrote offering me access to this archive, on conditions which included an undertaking that I would not divulge anything from this archive without the prior permission of the President, I readily assented.

This agreement, as come to in October 1986, was never carried out. A series of bureaucratic and other obstacles was placed in the way of its implementation until, in May 1988, it was made clear to me by Dr. Kopelowitz that access to the archive would depend not merely upon my adhering to conditions to which I had already agreed, but also upon my agreeing to other, new conditions which had nothing remotely to do with the archive itself, but which pertained to my role and profile in a quite different communal matter. In other words, my access to the archive was now dependent upon my keeping my mouth shut on a current matter then of great communal interest and importance.

Was there ever, I wonder, such pressure put upon a professional historian working in the field of Anglo-Jewish history as was put upon me at that time? And could there, I wonder, be a more perfect example of the contempt in which British Jews - at least as represented by the Board - holds those who seek the truth of its history? Throughout all these - and other - trials and tribulations I was constantly assailed by members of Anglo-Jewry. I was told to be careful what I wrote and how I wrote it. I was enjoined to present Anglo-Jewry in a favourable light. I was told not to say anything that might be used as ammunition by antisemites.

I replied, and I reply, as follows. If, as I sit in front of my laptop, my constant intent is not to write anything that may be used by the detractors of the Jewish people, then the detractors have already, thereby, won a victory. That is not a victory I propose or have ever proposed to give them.

\footnotetext{
9 On this episode see G. Alderman \& C. Holmes, 'The Burton Book,' Journal of the Royal Asiatic Society vol.18, no. 1 (January 2008), 1-13.
} 
I recall, and commend, some words penned by one of the greatest novelists and poets to write in the English language, Thomas Hardy. In the 'Explanatory Note' to the first edition of his great novel Tess of the D'Urbervilles, written in November 1891, Hardy felt it prudent to remind his audience of some words of St. Jerome. I repeat them now, and I have no qualms about doing so since I follow the maxim of the late Chief Rabbi Hertz, who enjoined his fellow Jews to accept the truth from whatever source it comes. ${ }^{10}$

The words of St. Jerome quoted by Hardy run thus: 'If an offence come out of the truth, better is it that the offence come than that the truth be concealed.'11

10 J. H. Hertz (ed), The Pentateuch and Haftorahs (2nd edn, London, 1969), vii: from the preface to the first edn, 1936: "Accept the true [sic] from whatever source it come, is sound Rabbinic doctrine - even if it be from the pages of a devout Christian expositor or of an iconoclastic Bible scholar, Jewish or non-Jewish.”

${ }^{11}$ T. Hardy, Tess of the D’Urbervilles (Penguin edn, London, 1985), 35. 
This is an Accepted Manuscript of a book chapter published by Routledge in Migrant Britain Histories and Historiographies : essays in honour of Colin Holmes on 23/08/2018, available online:

https://www.routledge.com/Migrant-Britain-Histories-and-Historiographies-Essays-inHonour-of-Colin/Craig-Norton-Hoffmann-Kushner/p/book/9781138065147 